\title{
Komunikasi Risiko Covid-19 dan Persiapan Menghadapi New Normal pada Masyarakat Kelurahan Air Putih Kota Pekanbaru
}

\author{
Suci Shinta Lestari' ${ }^{1}$, Muhammad Arif', Muhammad David Hendra3 ${ }^{3}$, Muhammad Hanif \\ Ahda $^{4}$, Nurul Mustaqimmah ${ }^{5}$, Feriandri Utomo ${ }^{6}$ \\ 1-6Universitas Abdurrab Pekanbaru \\ E-mail: suci.shinta@univrab.ac.id
}

\begin{abstract}
Abstrak
Penularan virus Corona sangat cepat. Dalam rentang waktu dua bulan, virus ini telah menyebar ke 28 negara, serta menginfeksi lebih dari 40.000 orang dan menewaskan lebih dari 1.000 orang di China. Hal ini membuat banyak orang panik sehingga keliru memahami informasi dan termakan hoaks. Penerapan komunikasi risiko yang memadukan unsur kecepatan dan akurasi sangat penting dalam mencegah penularan Covid-19. Di mana dampak sosial dan ekonomi akibat penyebaran informasi yang salah bisa lebih parah dibanding penyebaran virus itu sendiri. Karena itulah, kegiatan ini dilaksanakan dengan tujuan mengendalikan kekacauan dan informasi yang berkembang di masyarakat, sehingga tidak menjadi bencana baru. Pemerintah, lembaga penelitian, dan pihak-pihak yang berwenang harus bisa mengomunikasikan risiko yang berlandaskan sains untuk menumbuhkan kepercayaan masyarakat. Tujuannya adalah agar publik bisa lebih siaga, mempersiapkan diri, dan mengurangi dampak yang ditimbulkan oleh Covid-19. Masyarakat butuh penjelasan bukan hanya oleh birokrat, tapi juga penjelasan yang ilmiah oleh para ahli. Ilmuwan dan pemerintah harus hadir untuk mengisi kekosongan informasi. Karena jika tidak diisi, dapat memberikan ruang untuk lahirnya hoaks. Untuk mendapatkan perspektif dari dunia kesehatan maka dalam pelaksanaan kegiatan ini dosen program studi Ilmu Komunikasi berkolaborasi dengan dosen Program Studi Kedoteran Universitas Abdurrab Pekanbaru.
\end{abstract}

Kata Kunci: Komunikasi risiko, Covid-19, New Normal

\begin{abstract}
Corona virus transmission is very fast. In a span of two months, this virus has spread to 28 countries, infected more than 40,000 people and killed more than 1,000 people in China. This has caused many people to panic so that they misunderstand information and are consumed by hoaxes. The application of risk communication that combines elements of speed and accuracy is very important in preventing transmission of the Covid-19. Where the social and economic impacts resulting from the dissemination of misinformation can be more severe than the spread of the virus itself. For this reason, this activity was carried out with the aim of controlling the chaos and information that developed in the community, so that it did not become a new disaster. Governments, research institutes and other authorities must be able to communicate science-based risks to foster public trust. The goal is so that the public can be more alert, prepare themselves, and reduce the impact caused by the Covid-19. Society needs explanation not only by bureaucrats, but also scientific explanation by experts. Scientists and governments must be present to fill in the information gaps. Because if it is not filled in, it can provide room for hoaxes to emerge. To get a perspective from the world of health, in the implementation of this activity the lecturers of the
\end{abstract}


Communication Science Study Program collaborated with the lecturers of the Medicine Study Program at Abdurrab University Pekanbaru.

Keywords: Risk Communication, Covid-19, New Normal

\section{Pendahuluan}

Di era teknologi informasi yang maju, berita apapun menyebar ke seluruh dunia dengan sangat cepat. Apalagi di era media sosial digital, berita yang menggemparkan dan menelan korban segera diunggah dan diperbincangkan orang per orang secara luas. Banyak bermunculannya hoaks yang berkaitan dengan Covid-19 diakibatkan minimnya informasi yang dikeluarkan oleh pihak-pihak yang memiliki otoritas. Dan, ketika salah satu pihak yang memiliki otoritas tersebut mengeluarkan informasi, tidak jarang malah tabrakan dengan informasi pejabat lainnya. Kekacauan informasi ini sebagai pemicu lahirnya pemikiran-pemikiran liar di publik. Dalam ranah analisis risiko (risk analysis) yang terjadi adalah kekacauan komunikasi risiko (risk communication). Kekacauan ini umum terjadi saat krisis, apalagi untuk krisis kesehatan seperti saat epidemi atau pandemi.

Krisis berupa wabah penyakit memang rentan terhadap pertentangan narasi informasi. Selain itu, pertentangan narasi informasi dalam suatu krisis kesehatan menjadi sulit dikelola karena tingkat ketidakpastiannya yang sangat tinggi. Dalam keadaan krisis seperti pandemi Covid-19, isi pesan yang diperlukan menyangkut transparansi mengenai ketidakpastian yang sedang berlangsung.

Mengacu urgensi analisis risiko (risk analysis), pandemi Covid-19 berada dalam kuadran keempat atau kuadran paling serius yang dicirikan oleh tingkat ketidakpastian dan kegawatan yang tinggi. Ketika sebuah krisis tergolong dalam kuadran keempat, yang diperlukan adalah proses analisis risiko yang ekstensif, bukan yang sedang-sedang saja, apalagi yang rutin (business as usual). Komunikasi risiko merupakan bagian tanggung jawab pengelolaan risiko. Pengelola risiko (risk manager) tidak harus turun gelanggang sendiri untuk mengomunikasikan risiko kepada publik, tetapi dia harus memastikan bahwa proses itu berlangsung dengan baik.

Pengalaman dari wabah ebola, SARS, dan H5N1 (flu burung) menunjukkan bahwa komunikasi publik saat krisis akan lebih efisien jika warga menaruh kepercayaan kepada pihak otoritas dan para ahli. Kepercayaan publik hanya bisa terbangun jika informasi tentang risiko yang disampaikan lengkap-utuh (komprehensif), transparan, dan mudah dimengerti serta didukung bukti atau teori ilmiah. Menurut tim pengabdian, komunikasi risiko yang dijalankan baik di tingkat nasional maupun daerah masih harus lebih optimal.

Dikutip dari laman WHO, komunikasi risiko merujuk pada pertukaran informasi, saran atau pertimbangan, dan opini secara real-time di antara para ahli dan masyarakat yang sedang menghadapi ancaman kesehatan, ekonomi maupun kesejahteraan sosial. Tujuan utamanya memampukan orang yang terpapar risiko mengambil keputusan 
berdasarkan informasi yang diperlukan untuk melindungi dirinya dan orang lain, mengubah keyakinan dan/atau perilaku.

Mematangkan rencana komunikasi risiko yang efektif adalah sebuah tantangan. Kita tidak menginginkan setiap imbauan, instruksi, atau kebijakan terkait penanganan wabah tidak diindahkan masyarakat. Apalagi jika kemudian sikap dan perilaku masyarakat justru kontraproduktif dengan apa yang diharapkan oleh pemerintah. Lihat saja bagaimana pelaksanaan pembatasan sosial berskala besar (PSBB). Lalu lintas masih ramai, kerumunan orang masih terlihat di pasar maupun terminal. Padahal, tak sedikit masyarakat yang sebelumnya menginginkan implementasi karantina wilayah atau istilah populernya lockdown. Hanya mungkin yang belum sepenuhnya dipahami masyarakat adalah baik PSBB maupun lockdown memiliki konsekuensi bahwa aturan tertentu akan ditegakkan. Mengingat sifat bencana yang risiko tertingginya adalah jatuhnya korban jiwa, maka kepatuhan masyarakat terhadap kebijakan pemerintah sangat krusial. Dengan catatan, kebijakan tersebut adalah kebijakan yang dinilai paling tepat untuk diambil. Sayangnya, disitulah letak tantangannya. Masyarakat semakin "kritis" dan memiliki banyak pilihan sumber informasi melalui berbagai platform, termasuk teknologi digital, sehingga mereka dapat membentuk opini sendiri terhadap kebijakan tersebut.

Komunikasi risiko dahulu dipandang hanya sebagai diseminasi informasi kepada publik mengenai risiko kesehatan dan terjadinya suatu peristiwa krisis kesehatan. Sekarang, komunikasi risiko harus lebih responsif terhadap perkembangan di lapangan, bersifat dua arah, serta lebih berorientasi pada solusi. Trio dis-informasi, mis-informasi, dan mal-informasi pada saat pandemi hanya akan menimbulkan kebingungan, ketidakpastian, kepanikan bahkan terpicunya pengambilan tindakan yang keliru di masyarakat. Itu di level individu. Bukan tidak mungkin keresahan itu akan terekskalasi lebih besar pada level berikutnya. Sifat kebaruan virus ini membuat sebagian besar informasi baru tentang penyakit ini lekas menjadi obsolet ketimbang menjadi kebenaran absolut.

Cara media bekerja sudah berubah karena tuntutan jurnalisme "24 jam" sehingga mengurangi kualitas dan kedalaman berita, meningkatnya jurnalisme warga, serta munculnya opini-opini versus sumber-sumber rujukan dari peristiwa lalu yang sumbernya terverifikasi. Menurunnya ketergantungan terhadap pakar di bidang medis diikuti dengan meningkatnya ketergantungan pada pendapat dari jaringan yang publik percayai.

Masyarakat harus mewaspadai munculnya pseudo-scientist, pakar palsu yang menyebarkan hasil analisisnya dengan sangat meyakinkan, namun tidak dapat dipertanggungjawabkan. Sehingga tidak sedikit masyarakat yang tergiring opini yang bisa jadi sangat membahayakan. Ditambah kehadiran para influencer yang dengan secuil informasi bisa mempengaruhi keyakinan fansnya. Dengan adanya logo sebuah instansi pemerintah pada vlog YouTube saja sudah bisa membuat penonton berpikir bahwa konten dalam video tersebut dapat dipercaya. Ketersediaan dan aksesibilitas yang tinggi 
terhadap informasi dapat membuat siapapun yang terpapar, tiba-tiba merasa telah menjadi yang paling paham tentang pandemi ini. Membuat mereka berani mengeluarkan pendapat dan menyebabkan perdebatan.

Istilah new normal muncul setelah banyak negara memutuskan melonggarkan lockdown atau penguncian untuk mencegah penyebaran virus corona. Melihat perkembangannya, banyak negara, termasuk Indonesia, memutuskan harus segera memulai kembali aktivitas di segala bidang dengan penyesuaian dan protokol baru untuk menekan risiko penularan dan penyebaran virus corona. Protokol yang ditetapkan ini menerapkan sejumlah kebiasaan-kebiasaan baru dan penyesuaian. Inilah yang disebut sebagai kenormalan baru atau new normal.

New normal adalah perubahan perilaku untuk tetap menjalankan aktivitas normal, tetapi dengan menerapkan protokol kesehatan untuk mencegah terjadinya penularan COVID-19. Dalam new normal, prinsip utamanya adalah penyesuaian pola hidup. Penyesuaian itu di antaranya protokol yang harus ditetapkan disesuaikan dengan kondisi tempat kerja, lokasi publik, dan sebagainya. Selain itu, tetap mengurangi kontak fisik dengan orang lain, dan menghindari kerumunan, serta menerapkan gaya hidup sehat.

Yang harus kita persiapkan menghadapi kehidupan kenormalan baru secara pribadi, adalah persiapkan mental untuk menerima segala perubahan kebiasaan yang akan terjadi. Semua orang diminta berperilaku hidup sehat dan memperhatikan protokol kesehatan pencegahan COVID-19 yang selama ini sering didengungkan. Protokol pencegahan itu di antaranya selalu menggunakan masker jika bepergian ke luar rumah, memahami etika batuk, tidak ke luar rumah jika tak memiliki kepentingan mendesak, rajin mencuci tangan dengan air bersih mengalir dan sabun atau menggunakan hand sanitizer dengan kadar alkohol minimal 60\%, tidak bertukar barang dengan orang lain di tempat kerja, misalnya membawa piring, gelas, dan sendok sendiri dan menghindari kerumunan.

\section{Metode}

Dalam kegiatan pengabdian ini yang menjadi subjek kegiatan adalah Masyarakat RW 09 Kelurahan Air Putih Kota Pekanbaru. Kegiatan dilaksanakan di Masjid Ar-rahman yang menjadi Masjid kebanggaan warga RW 09 Jl. Garuda Sakti. Untuk Memudahkan mobilisasi massa maka kegiatan dilaksanakan pada hari Jumat, 3 Juli 2020 setelah sholat Jumat.

Kegiatan pengabdian ini merupakan kerjasama Program Studi Ilmu Komunikasi Universitas Abdurrab dengan Program Studi Kedoteran Universitas Abdurrab, Forum Osis Pekanbaru dan Volunteer Kindness Pekanbaru dimana sebagaian besar anggotanya merupakan pemuda - pemudi RW. 09 Kelurahan Air Putih.

Kegiatan pengabdian dilakukan selama satu hari dimulai dengan temu ramah kepada pemuka adat, tokoh-tokoh yang dituakan di RW 09 seperti ketua RW 09 Kelurahan Tanah putih. Untuk setiap warga yang masuk kedalam masjid diberikan 
masker dan diminta untuk mencuci tangan di tempat cuci tangan yang telah diserahkan oleh tim pengabdi dan diletakkan dipintu masuk masjid Ar-Rahman. Kegiatan baru dilaksanakan setelah sholat Jumat. Dengan pendekatan persuasif, warga RW 09 banyak yang masih bertahan di Masjid untuk mendengarkan materi yang disiapkan oleh tim pengabdi.

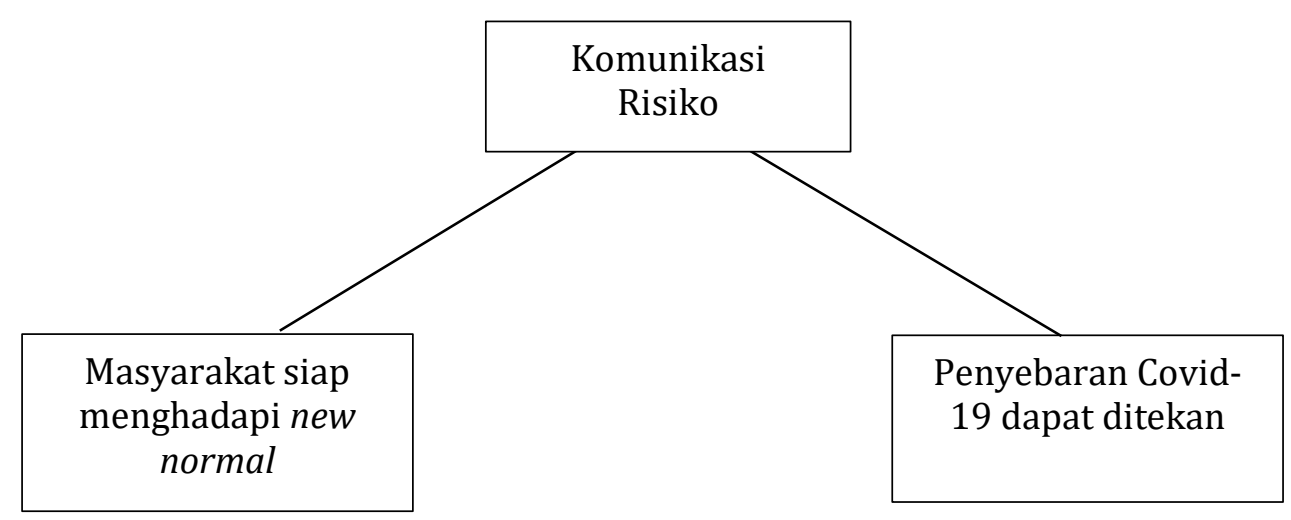

Gambar 1. Kerangka pikir kegiatan

Strategi yang digunakan :

1. Menjalin kerjasama dengan Forum Osis SMA/SMK/MA Sederajat atau organisasi kepemudaan di Pekanbaru untuk penentuan lokasi pengabdian dan penentuan masyarakat sasaran sehingga kegaiatan berbasis kebutuhan masyarakat

2. Pembuatan materi berup apresentasi slide power point dengan merujuk pada materi Komunikasi RISIKO Covid 19

3. Pemberian materi sekaligus mengakomodir feedback berupa tanya jawab tentang materi untuk melihat pemahanan yang dialamai oleh audiens.

4. Penyerahan Fasilitas cuci tangan dan pembagian masker gratis bagi warga RW 09

5. Dilaksanakan simulasi pengecekan suhu tubuh dan cuci tangan yang bersih

6. Teknik penyelesaian masalah melalui penyajian materi dengan presentasi power point secara interaktif serta memastikan tercapainya peningkatan pengetahuan dan perubahan prilaku audiens. Ketercapaian diukur dengan melihat respon audiens dan melihat perubahan yang terjadi pada diri audiens apakah mematuhi protokol kesehatan sebagai bagian yang tidak dapat dipisahkan dari upaya menghadapi era new normal.

\section{Hasil dan Pembahasan}

Catatan tim pengabdi berdasarkan berbagai sumber informasi, masyarakat di RW 09 termasuk kelompok masyarakat yang mudah dalam mengakses internet namun belum diiringi dengan kualitas sumber daya manusia yang memadai. Informasi terkait 
Risiko yang ditimbulkan akibat abai terhadap protokol kesehatan sangat vital bagi masyarakat saat ini, namun tidak mudah juga menyampaikannya ditengah masyarakat yang selalu merasa lingkungan dan kelompoknya tidak akan terinfeksi Virus corona. Karena aspek geografis yang jauh dari zona merah dan jumlah warga yang dianggap sedikit. Untuk itulah tim pengabdi dalam kegiatan ini berusaha sangat keras mengemas pesan sedemikian rupa agar tidak menimbulkan persoalan yang dapat saling bersinggungan dengan hak dan kewajiban masyarakat.

Tim pengabdi memberikan pemahaman kepada warga RW 09 bahwa kemampuan mengolah informasi sangat penting agar informasi terkait kesiapan mengahadapi new normal dapat diberdayakan menjadi alat untuk kesejahteraan masyarakat ditengah pandemi. Keberlangsungan hubungan sosial kemasyarakatan (Horizontal), peribadatan (Vertikal), ekonomi, politik, pendidikan tetap berjalan dengan kenormalan baru.

RW 09 Air putih Pekanbaru yang merupakan kawasan pemukiman dengan masyarakat yang heterogen dari aspek profesi, pendidikan dan tingkat sosial. Harapannya mayarakat di RW 09 Air Putih Pekanbaru akan menjadi lebih siap dalam menghadapi era new normal dan menjadi percontohan masyarakat yang terliterasi, dapat menyaring segala informasi terkait Covid-19 sehinga hoaks dan bahaya covid19 dapat ditekan.

Masyarakat diberikan pengetahuan untuk dapat mengenali hoax dalam isu kesehatan. Pertama, biasanya menggunakan kata-kata provokatif seperti misalnya 'sekedar info untuk anak kost' 'wajib dibaca bagi yang muslim' 'wajib share jika ingin masuk surga' dan sebagainya. Di media sosial, biasanya kalimat provokatif ini akan diikuti emoticon atau tanda seru berwarna merah dan sebaganya. Kedua, nama dokter pencetus informasi tidak disebutkan, yang disebutkan hanya 'seorang dokter dari jepang' atau disebutkan tanpa nama lengkap misalnya 'dr. Gaitsa menyebutkan....' dan nama dokter yang dirujuk biasanya merupakan nama-nama yang umum atau hanya nama pendek hal ini dilakukan untuk mempersulit verifikasi. Ketiga, informasi dipaparkan dengan sangat panjang dan menggunakan kasus yang sangat dramatis. Misalnya 'ada seorang wanita meninggal mendadak dengan mata terbelalak karena menggunakan provider three saat petir', dalam pemaparannya juga sering tidak disebutkan lokasi kejadian dan jika ditelusuri di berbagai media maka kita tidak menemukan informasinya. Keempat, diakhiri dengan mengajak untuk menyebarkan informasi tersebut seperti 'copy paste lah jika anda merasa ini cukup penting, kasihanilah keluarga anda'.

Pada saat pelaksanaan kegiatan hampir seluruh pertanyaan dari masyarakat bisa dijawab dengan baik oleh narasumber. Kolaborasi dosen program studi Ilmu Komunikasi dengan dosen program studi kedokteran saat pelaksanaan kegiatan pengabdian membuat materi yang sampai pada warga RW 09 menjadi lebih objektif dan komprehensif. Aspek risiko dijelaskna secara rinci oleh dosen ilmu komunikasi dan aspek kesehatannya dijelaskan secara rinci oleh dosen kedokteran. 
Selanjutnya perlu dijajaki kemungkinan pelaksanaan kegiatan rutin dan berkelanjutan, mengingat angka penyebaran covid 19 semakin signifikan. Keberlanjutan program dapat dilaksanakan dengan menambah materi tentang rekomendasi kebijakan pemerintah terkait sanksi pelanggar protokol kesehatan. Diharapkan hal ini dapat terlaksana dengan melibatkan banyak pihak baik dosen maupun mahasiswa sebagai salah satu bentuk tridharma perguruan tinggi.

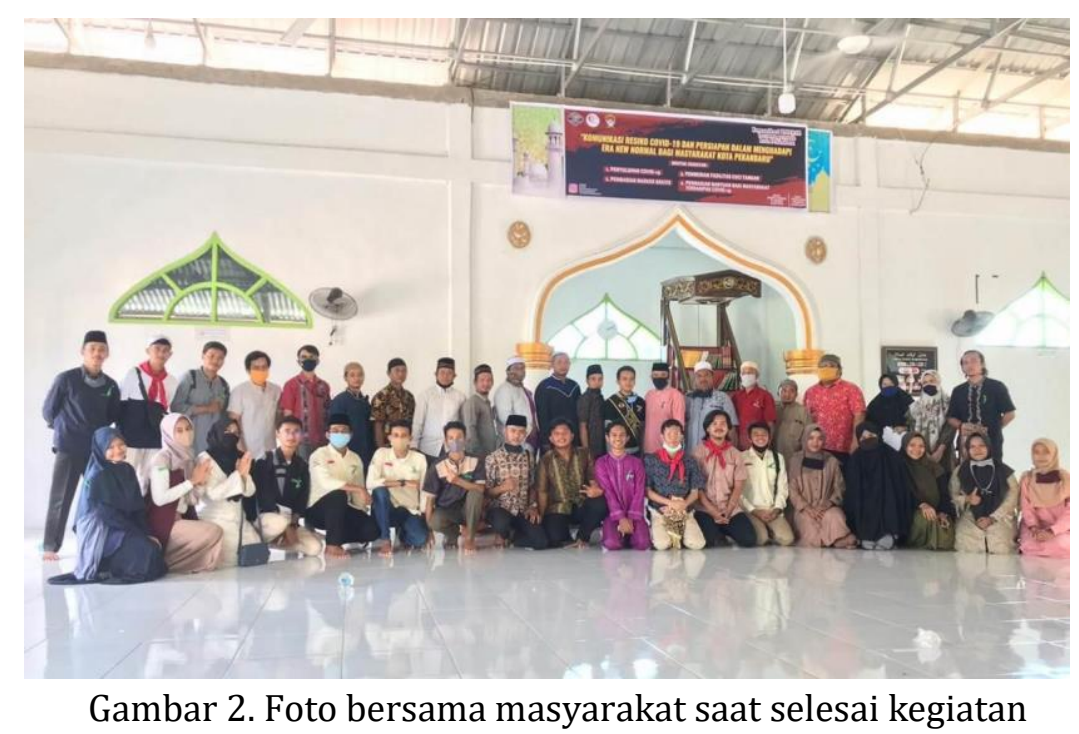

Sebelum foto bersama, telah dilakukan simulasi pengecekan suhu badan, cuci tangan dengan sabun dengan fasilitas cuci tangan yang dihibahkan untuk Masjid RW 09.

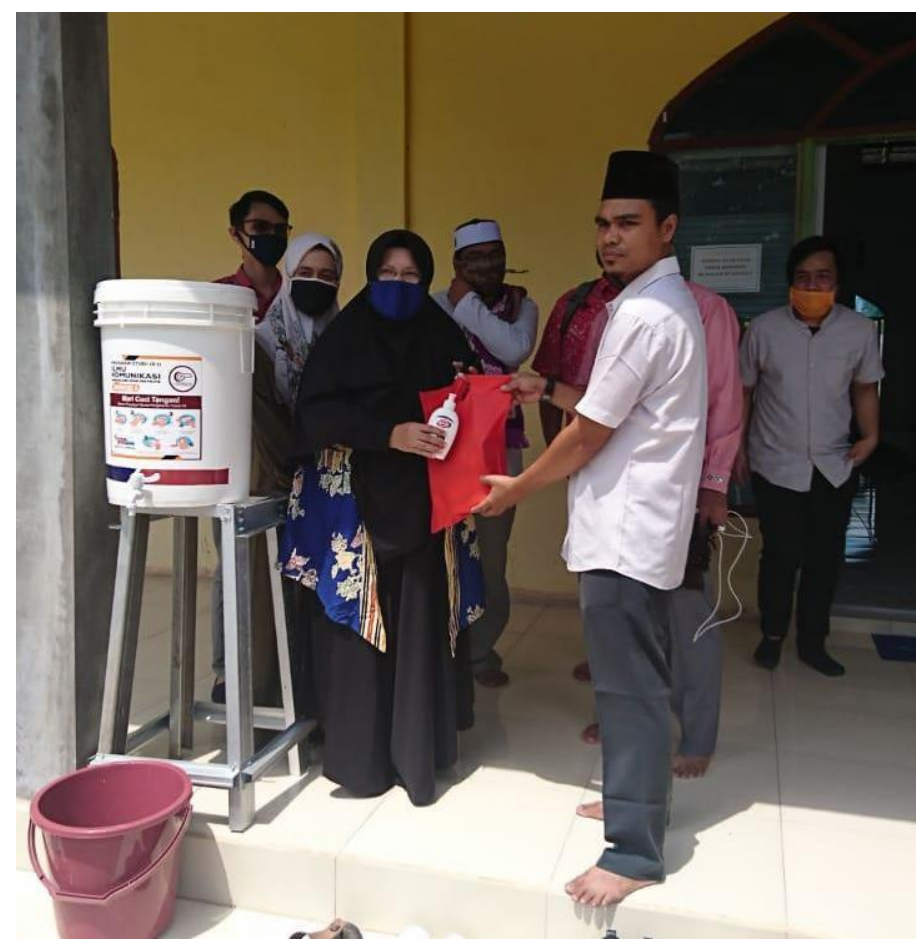

Gambar 3. Penyerahan Fasilitas cuci tangan untuk warga RW 09 


\section{Simpulan}

Setelah kegiatan pengabdian berlangsung, proses evaluasi pelaksanaan kegiatan dilakukan dengan menganalisis isi lembar testimoni yang telah diserahkan kepada warga RW 09. Dari hasil analisis diketahui bahwa telah terjadi peningkatan pengetahuan tentang Covid 19 sehingga warga dapat mengurangi penyebaran berita hoaks dengan terlebih dahulu melakukan kroscek sebelum menyebarkannya kembali ke khalayak lain. Dengan informasi yang benar, masyarakat RW 09 siap menghadapi era new normal, mereka juga dapat mengembangkan dan mencapai kehidupan yang lebih baik secara sosial di era pandemic covid dan informasi saat ini sehingga penyebaran Covid 19 dapat diminimalisir.

Komunikasi risiko juga dirasakan lebih dari sekedar diseminasi informasi kepada publik mengenai risiko kesehatan dan terjadinya suatu peristiwa krisis kesehatan. Komunikasi risiko yang sampaikan tim pengabdi lebih berorientasi pada solusi menghindari munculnya kebingungan, ketidakpastian, kepanikan bahkan terpicunya pengambilan tindakan yang keliru di masyarakat.

Melihat pentingnya peran media dalam membagikan informasi kesehatan, maka pemanfaatan media juga harus tepat. Misalnya memanfaatkan media digital. Pemanfaatan media untuk penyebarluasan informasi kesehatan disatu sisi membantu kita untuk mencari informasi seputar kesehatan secara mandiri. Di sisi lain, terdapat juga dampak negatif. Hal ini karena internet yang mudah penggunaannya menjadi sumber informasi memunculkan kondisi banjir informasi. Informasi hadir begitu saja dihadapan kita. Hasan dalam laporannya di Tirto.id (2017) mengemukakan angka tertinggi hoax yang beredar di masyarakat adalah hoax tentang kesehatan yakni sebanyak $27 \%$. Angka tersebut engalahkan hoaz bidang politik yang persentasenya $22 \%$ untuk itulah perlu pengetahuan mengenali hoax dalam isu kesehatan (komunikasi risiko).

Dalam kegiatan pengabdian masyarakat ini, tim pengabdi memberikan informasi tentang cara melakukan literasi kesehatan, pertama tidak buru-buru menyebarluaskannya ke khalayak sebelum membaca secara tuntas informasi yang didapat, kedua mulai mempertanyakan informasi yag didapat. Karena dengan mulai mempertanyakan kita akan mulai mencari perbandingan infomasi yang didapat dengan informasi lainnya. Sikap tidak mudah percaya sangat dibutuhkan. Ketiga, menyaring informasi yang diperoleh dan kemudian mulai menelaah proses menolak atau menerima informasi.

Tim pengabdi juga merekomendasikan beberapa tindakan, yakni : perlunya penjajakan kemungkinan pelaksanaan kegiatan menjadi rutin dan berkelanjutan dimasa pandemi dan perlunya kolaborasi dengan berbagai bidang sehingga materinya menjadi lintas sektoral. 


\section{Referensi}

Birowo, M. A. (2019). Literasi media \& informasi dan Netizenship ; LMI dan Citizezenship. Program Studi Ilmu Komunikasi FISIPOL Univ. Atma Jaya Yogyakarta.

Hasan, A. M. (2017). Info hoax soal kesehatan paling banyak beredar di masyarakat. Retrieved from https://tirto.id/info-hoax-soal-kesehatan-paling-banyak-beredardi-masyarakat-cnQZ

Suparmo, L. (2018). Manajemen krisis isu dan risiko dalam komunikasi. Jakarta: CV. Campustaka

Puspitasari, L. (2020). Pandemi, Komunikasi Risiko, dan Kepercayaan Publik. Retrieved from https://news.detik.com/kolom/d-4997263/pandemi-komunikasi-risiko-dankepercayaan-

Vidiadari, I. S. (2019). Literasi media \& informasi dan Netizenship ; LMI dan kesehatan. Program Studi Ilmu Komunikasi FISIPOL Univ. Atma Jaya Yogyakarta.

Widianarko, B (2020). Komunikasi RISIKO, memastikan ketidakpastian. Retrieved frorm https://news.unika.ac.id/2020/05/komunikasi-risiko-memastikan-

ketidakpastian/https://ksp.go.id/wp-content/uploads/2020/03/ProtokolKomunikasi-COVID-19.pdf 